\title{
Identification of Triphthongs in Pakistani English
}

\author{
Mahwish Farooq ${ }^{1} \&$ Asim Mahmood ${ }^{1}$ \\ ${ }^{1}$ Department of Applied Linguistics, Government College University, Faisalabad, Pakistan \\ Correspondence: Mahwish Farooq, Department of Applied Linguistics, Government College University, \\ Faisalabad, Pakistan. E-mail: mahwishfarooq4@gamil.com; asimrai@gmail.com
}

Received: June 2, 2017 Accepted: October 18, 2017 Online Published: October 25, 2017

doi:10.5539/ijel.v8n1p184 URL: https://doi.org/10.5539/ijel.v8n1p184

\begin{abstract}
The present research deals with the identification of triphthongs in Pakistani English (PakE). A triphthong is the combination of three different vowels. There are five triphthongs in English (Roach, 2009) but those are absent in PakE due to the language variation phenomenon. As, we know that every language has a different lingual approach than the other therefore, if we find any similarity that is just a matter of chance and coincidence nothing else. So, in the current research, it is proposed that the native language, Urdu would affect standard pronunciation or RP in Pakistan. For the confirmation of this hypothesis, two experimental approaches are selected for the identification of triphthongs and their acoustic behavior in PakE. Therefore, sixty Pakistani speakers have been selected as a population of the research. Afterwards their speech has been recorded and analyzed in anechoic chamber. In the first step, the auditory approach has selected which reported varied vocalic segments by using syllable count method. In the second step, for knowing the acoustic behavior, the identified segments have been further investigated in PRAAT software. Then, data analysis and results have confirmed that Urdu influences and transforms the acoustic features of PakE. It is also confirmed that PakE has two triphthongs; (i) /vae/ (at word final position) and (ii) /val/ (at word medial position) which are not the part of RP phonetic inventory.
\end{abstract}

Keywords: Pakistani English, triphthongs, acoustic analysis

\section{Introduction}

In Pakistan, English is an official language (Rehman, 2002) therefore, plays different functions (Kavaliauskiene, 2009; Mehboob, 2003). It is also considered a powerful medium of instructions and has decided a compulsory subject for private and public sector institutions (Lewis, Paul, Simons, \& Fen, 2016). Therefore, it is self-evident for Pakistani people that English language is a key to success. It would be right to say that English learning is being stressed for getting success in the competition of communication (Romaine, 1994). Along with this, the importance of Urdu is irrefutable as a largely comprehended language of Pakistan. Therefore, Urdu nativeness effect directly influences English Language Learning (ELL) which supports our hypothesis. As, language is a "living organism" therefore receives continuous changes and diversities (Amberg \& Vause, n.d.). It is also confirmed phenomenon that language acquisition and learning are closely linked. Because language acquisition is the initiator and learning is the monitor of an utterance (Koucka, 2007) therefore, in the current research, this relationship has been investigated with reference to Urdu language.

Although PakE comes under British Standard but still have differences because of different factors. Those are; (i) learners' acquisition, (ii) non-native English teachers and their language proficiency, (iii) different phonetic inventory, (iv) sociocultural issues, (v) academic problems, (vi) acoustic training of vocal apparatus, (vii) multilingualism (Farooq, 2015) where Urdu is our national language (Rehman, 2006) and mother tongue (Zia, 2011). But in this research only the acoustic training would be discussed for knowing the behavior of triphthongs. Because, triphthongs are complex sounds (Roach, 2009) and their pronunciations generate a debatable difference. Such differences are based on the phenomenon that each language has distinct phonemic inventory which is different even within the dialects of a language.

The basic purpose of this research is to deal with the mystery of language change; faced by non-native English speaking countries (even by Pakistan) as they are producing different varieties of English language. Therefore, it is the demand of time to develop standard models and norms for solving different internal variations among "Englishes" of the world. By considering this matter and research limitation, the current research is only based 
on the acoustic analysis of speech for identifying segmental differences in PakE. Therefore, two experiments have been done for the confirmation of language differences i.e., (i) auditory analysis is done for the identification and (ii) acoustic analysis deals with the confirmation of triphthongs and their acoustic behavior. Then, the data analysis has confirmed the presence of two triphthongs (/vae/ and /va/) and their idiosyncratic behavior in PakE. Therefore, it would prove a positive addition in the phonetic inventory of PakE which will ultimately acknowledge it as an independent variety among other "Englishes".

\subsection{Relevant Literature}

In Pakistan, it would be first research for the identification of triphthongs in PakE speech. Therefore, it is based on the acoustic analysis of possible differences and their motivations. Before starting the matter of discussion, the background of the research is the most important element. Actually, due to the prestige of English as an international language across the world, people have realized the need of time to learn English for their own benefits (Sharifian, 2004) which becomes the cause of different Englishes. Therefore, it has become an ultimate reason to make standards for different local Englishes by making them independent variety and same is the case with Pakistani English variety.

According to Kachru, local English reflects local culture and norms therefore he has introduced "polymodel" of language for categorizing different Englishes (as cited in Kirkpatrick, 2004). Although, SLA paradigms have refused language variations by considering it "negative transfer" on the bases of "native variety". But actually, these varieties must be evaluated within their cultures as people are psychologically linked with their cultures. Therefore, the people of overlapping language varieties share mutual conceptualization of communication and cultures (Ramanujan, 1990). No doubt, English is a global language and is being spoken by a number of different language speakers. Evidently, almost $80 \%$ English communication has taking place in non-native countries (Sharifian, 2004). Therefore, it is gradually changing by different means (Modern Englishes, 2012). The same is the purpose of the current investigation where PakE has been acoustically analyzed for knowing the effect of native language, Urdu on RP. It has been discussed in the subsequent sections.

\subsubsection{First Language influences Second Language Learning (SLL)}

The use of first language in Second Language Learning (SLL) is a controversial matter of discussion and there are different counter arguments by different schools of thought. For example, Dulay \& Burt (1974) suggested that first language indirectly influenced SLL therefore learners were unable to identify the interference of their first languages. That would ultimately become the reason for the alternation and variations in second language. Therefore, it was claimed that if a non-native speaker learn second language without using his first language then he would be more efficient. For SLL, the second school of thought claimed the importance of using first language by giving the reference of Grammar Translation Method, GTM (Tema, n.d.). But it received a counter attack that Second Language Acquisition (SLA) along with the first language would be challenging for learners. Then, again it was claimed that prohibition of a language and authorizing to another language would become the reason for learners' nervousness (Amberg \& Vause, n.d.). We can conclude it by saying that SLA is an organized process of language learning where phonological constraints add nativeness flavor in second language (Mahmood, Hussain, \& Mahmood, 2011) which would be considered a normal language behavior.

In Pakistan, English is a "must-have language" due to its significant role (Mahmood et al., 2011) therefore declared as a compulsory subject and element for bilingual education (Mahboob \& Jain, 2016). Moreover, Higher Education Commission (HEC) launched English Language Teaching Reforms (ELTR) program for revolutionizing the existed teaching methodologies by providing training to English teachers which would be helpful for achieving required results. Otherwise, passive policies without their practical implementations would be useless to bring any positive change in reality (Mehboob, 2003).

\subsubsection{Urdu influences English Language Learning}

In Pakistan, according to a research, use of English language is not limited to educated people only but uneducated people also use English vocabulary in their daily communication. The reasons might be media influence and the class consciousness. Their speech is not a mere reduplication but is a continuous process of phonological make-up initiated by the phonetic constraints of their native language. Therefore, multiple pronunciations occur under the umbrella of language change and variation (Riaz, 2015).

In Pakistani English literature, the use of "Urduised" vocabulary has directly influenced PakE by the addition of new lexical entries which represents distinctive and indigenous culture of Pakistan. It links localization by the demonstration of PakE as an independent variety among other Englishes (Ahmad \& Ali , 2014). All these researches have supported the nativeness effect of Urdu language on RP or Standard English which would be 
helpful for PakE for making it an autonomous English variety.

\subsubsection{Pakistani English (PakE)}

Linguistic variation is an important reason for the dialectal variation in PakE (Schneider, 2010). Actually, first language defines the regional dialects of a language variety in a country. We know that Pakistan is a multilingual country and has speakers of sixty languages (Farooq, 2015) which may become the cause of dialectal variations in PakE. Dialectal variations further cause phonological, syntactical, morphological and even semantic variations in Pakistani English variety (Mahboob \& Szenes, 2010). The present study only deals with the phonological variations of PakE. For instance, it is phonologically different by having different phonetic features (Khan, 2012). Urdu and Punjabi influenced PakE by vowel substitution and alternations (Hussain, Mahmood, \& Mahmood, 2011; Bilal, Mahmood, \& Saleem, 2011; Bilal, Mahmood, \& Saleem, 2011; Bilal, Mahmood, \& Saleem, 2011; Mahboob \& Ahmar, 2004).

PakE belongs to the outer circle Englishes where full vowel articulation is a shared tendency of speech communities (Crystal, 1985, (2003)) which makes them different from the standard norms but would be identified as one possible standard. Ultimately, it would raise self-confidence among non-native English teachers and leaners to continue their norms of pronunciation (Kirkpatrick, 2007). Besides this, it would make them believe that English is also their own language as for anyone else (Deterding, 2010). This principle supports our current research as well because language nativeness effect triggers acoustic differences by producing alternative pronunciation. Such type of alternative pronunciation ultimately changes RP and would become reason for the phonetic inventory of PakE.

\subsection{Phonetic Inventory}

Every spoken language has a phonetic inventory which is the set of different consonants, monophthongs, diphthongs, triphthongs (Skandera \& Burleigh, 2005; Roach, 2009). A consonant is articulated with breath restriction in oral or nasal tract. Vowel is articulated without any obstruction of air stream (Roach, 2009). Monophthong is a kind of vowel but is larger than a vowel which may be equal to a diphthong (Mahajan, 2014). Diphthong has no apparent consensus for the phonetic definition but normally it is considered the combination of two vowels by showing dual targets and a transition period (Lee, Potamianos, \& Narayanan, 2014). But according to the research limitations, only triphthongs have been discussed in detail.

\subsubsection{Triphthongs}

Conventionally, vowel sequences which consist of three vowel sounds are called triphthongs. It is a term derived from the Greek word "triphthonggos" which means "triple sound" (Wells, 1982). For the articulation of a triphthong, tongue initially occupies a position which gradually changes and occupies different position at the end. In other words, we can say that it maintains the difference which deals with three different vowels within one syllable. For example, if there is one sound in a syllable than it would be a vowel or monophthong, a diphthong would be in case of two vowel sounds in a syllable and three distinctive vowel sounds in a syllable is called a triphthong. A monophthong, diphthong or triphthong is almost similar in length. It is an ultimate reality that rhotic dialects have no triphthong or in some cases even no diphthong (The Phonology of English Vowels: An Introduction).

Several languages have different number of triphthongs e.g., Romanian has two triphthongs while Northern Bavarian, Bernese German, Spanish and Portuguese have four triphthongs but Vietnamese has eight triphthongs (Wells, 1982) whereas English has five triphthongs i.e., /avə/, /агə/, /əəə/, /əбə/, and /егə/ which are comprised of any closing diphthong followed by a short vowel schwa / $/$. The existence of triphthong is a controversial phenomenon in RP or BBC 

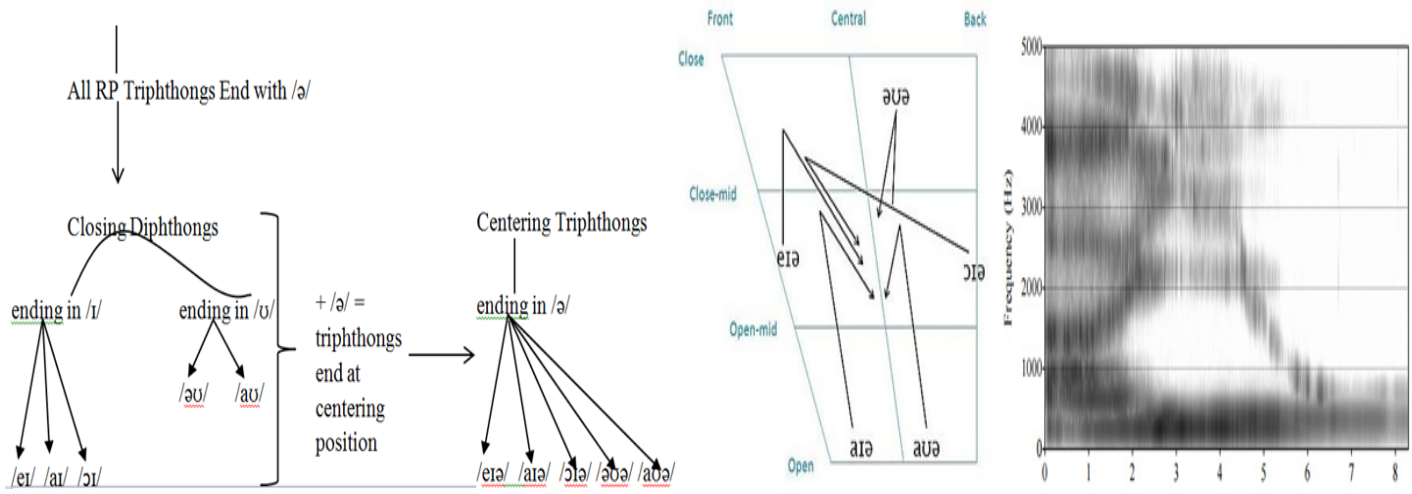

Figure 1. English Triphthongs

Source: http://www.phonologythree.blogspot.com; http://www.fon.hum.uva.nl/paul/papers/AcousticAnalysis8.pdf

English because neither dictionary nor any linguist has claimed its presence except Roach. But he also has claimed for the possible existence of only two triphthongs in the pronunciation of

"words such as "fire" /faia/ or "hour" /avo/ are probably felt by most English speakers (with BBC pronunciation) to consist of only one syllable, whereas "player" /pleıə/ or "slower" /sləvə/ are more likely to be heard as two syllables" (Roach, 2009, p. 19, Para 2)

He did not explain triphthongs in detail and gave the reason that

"there is no much variation in the amount of vowel movement according to how slow and careful the pronunciation is and also because the "careful" pronunciation can be found by looking at the description of the corresponding diphthong and adding /o/ to the end". (Roach, 2009, p. 19, Para 3)

In other words, triphthongs are difficult to recognize in connected and fluent speech. Therefore, if speakers were ask to pronounce such words in "slow and careful" manner then there were more chances for the articulation of a diphthong followed by a separate /a/ sound.

Triphthong has described differently in previous studies. Firstly, it is considered a complex sound difficult to articulate and recognize which has an uninterrupted glide movement from first to second then to a third vowel (Roach, 2009). Secondly, it creates major cause of difficulty for second language learners. Thirdly, segmental duration is another clue which is very short but duration may increase during conscious articulation. Fourthly, the middle vowel loses its phonetic features due to the influence of adjacent vocalic segments. Fifthly, the syllabic identification and count is difficult for the non-native speakers (Wells, 2009). Sixthly, a triphthong has three articulation positions depending upon the vowels' quality (Wells, 1982).

For the acoustic measurement of a triphthong, Nearey \& Assmann (1986) had introduced a term named as Vowel Inherent Spectral Change (VISC). It refers the change in spectral properties of the sound wave over a time period which ultimately refers the characteristic of vowel identity. It is not only used for diphthongs and triphthongs, but also for monophthongs as well. Different researchers had used same terminology in different time periods even in early 19th century (as cited in Hillenbrand, 2013; Joos, 1948; Potter \& Steinberg, 1950). Along with this, static spectral models of vowels have predominated in phonetics research. Although the situation remains in static condition due to a number of researchers are practicing in different sub-branches of phonetics for investigating or incorporating VISC as a factor of their wider experimental research design (Hillenbrand, 2013).

For computational sciences, a model named as a "third-order polynomial" has been selected on the basis of speaker specific information which could be extracted from the formant trajectories of diphthongs (or triphthongs) but the more complex models began by fitting noise. Later in 2011, Zhang et al. has introduced a fourth order DCTs on F2 and F3 which gives best performance results for a forensic voice comparison system which is based on the tokens of Standard Chinese triphthong /iau/. Afterwards, F pattern variations for adjacent sound patterns have been used (Rose \& Wang, 2016; Emerich, 2012; Man, 2007; Fant, 2006). But it can be concluded by considering that transition period of gliding segments are not helpful for individual vowel identity but provide crucial information for the identification of a gliding phoneme (Weirich, 2011).

Finally it is an ultimate reality that English is global and universal language which is required for the successful life. Therefore, a large number of non-native people are using it as a "communication tool" for individual and 
national excel. Consequently, non-native speakers add nativeness effect at different levels consciously or unconsciously. Among them, phonological variation is the most prominent level of speech which confirms that every spoken language has its own inventory. Vowels are significant speech segments because speech quality is vowel dependent. Triphthong is an important and complicated vocalic segment. There is controversy in the presence of triphthongs in RP but in any case, these triphthongs are not the part of PakE (Farooq \& Mahmood, 2017). The current research is done after considering the literature review. Therefore, it is investigated whether we Pakistani speakers can articulate a triphthong or not. If yes, then how many in numbers they are?

\subsection{Research Questions}

The hypothesis of the research is whether the first language, Urdu will affect RP in Pakistan or not? Therefore, it will answer the following questions;

a. Is there any triphthong in PakE?

b. If yes, how many in number they are?

\section{Methodology}

\subsection{Participants Characteristics}

60 Pakistani English speakers are selected as a sample by following convenience sampling method. The sample group is balanced in number as they are 30 male and 30 female speakers and their ages range betwen 18-25 years. They are graduates of different Public Sector Universities. The first reason to select them is their good comprehension for English language. The second reason is that a graduate is considered an individual who is equally attached with his first and second language.

\subsection{Research Design}

This research is epistemological in nature because directly relates with positivism and results are acquired by using scientific proves. Accordingly, area of acoustic-phonetics has been selected for doing contrastive analysis in order to identify the presence of triphthongs and their acoustic behavior in PakE. The basic purpose behind the study is to investigate the nativeness effect of Urdu language on PakE.

\subsection{Experimental Manipulations}

Afterwards, their speech is recorded and analyzed in PRAAT (Boersma \& Weenink, 1992-2013). PRAAT software is used for synthesizing, analyzing, and manipulating speech sound waves after visualizing their variations (Boersma, 2013). So, the list of words (which contains RP diphthong/OI/) has been selected for constructing a text corpus containing 17 sentences which are used for recordings. The reason to select them is; it has been observed that Pakistani speakers are randomly substituted/sI/ diphthong with other vowel(s). Therefore, in order to find the truth, this current research is done. Then, the speech has been recorded in anechoic chamber at $48000 \mathrm{~Hz}$ in PRAAT by using high fidelity microphone, amplifier, and headphone. Later, this speech is used for the development of annotated speech corpus which ultimately served as a research data for the acoustic analysis. This speech data is annotated phonologically with the help of Case Insensitive Speech Assessment Method of Phonetic Alphabets, CISAMPA. This annotation is done for avoiding machine errors. During annotation, each vocalic segment is analyzed after measuring its segmental variations like duration, formant frequencies, segmental alternation, etc. These physical properties have identified the unique triphthongs and their acoustic behavior in PakE.

\section{Results}

Spectral analysis of wave form is not enough for the identification of a triphthong therefore spectrogram is also used as it plays important role. The reason to use both is the variable frequency of a triphthong which gradually changes with the time. In that way, it follows the processing format of basilar membrane of the inner ear which has divided the sound on the basis of frequency at every interval of time. Due to pitch, the problem of sound consistency also occurs therefore a spectrum cannot be analyzed for a single moment of time. Instead of this, it is assumed; the spectral property of a sound remains stable for at least 5 milliseconds of time interval therefore it is required to determine the spectrum of each slice separately. Such a short span window of 5 milliseconds is called "broadband spectrogram". Time increases along horizontal axis and frequency on vertical axis. Therefore, formant analysis also proves helpful for identifying a triphthong by using source filter theory where vibration of vocal cords is consider source and the resonance of vocal tract is considered as a filter. In order to enhance reliability, a number of measurements have been taken afterwards their median is calculated for minimizing the gross measurement errors (Boersma, 2013).

Duration is also a property of phoneme in context of time and timing of speech production. The reason to use 
duration clue is; vowels are directly affected in duration with a number of factors e.g. vowel's position in a phrase, speaking rate, adjacent consonants, syllabic stress, type of the word, emphasis assigned to the word by a speaker and numbers of syllables in a word. Gliding segments or triphthongs follow similar rules (Khurshid, Usman , \& Javaid, 2003-2004). But the present research is a comparative study for the identification of the triphthongs and their acoustic behavior in PakE. Therefore, the whole process is divided in two steps; (i) auditory experiment and (ii) acoustic experiment.

\subsection{Auditory Experiment}

Auditory experiment is based on the listening comprehension and skills of a linguist. The selected English text is asked to record by 60 Pakistani English speakers for verifying the hypothesis. The used text has 17 sentences where the content words contained RP diphthong / $\mathrm{J} /$ / (in 17 sentences x 1 vocalic segment x 3 repetitions x 60 speakers $=3060$ utterances). This corpus is selected for the justification whether Pakistani English speakers articulate /oI/ diphthong or any other alternative segment. Earlier, the text is recorded in the connected speech. Later, for the confirmation of the results every speaker has been asked to repeat each word three times in a carrier phrase. Then, these recordings have been processed by two linguists for the auditory identification of triphthongs. Therefore, a checklist is also built for syllable count because it's a good hint (Bhatti \& Mumtaz, 2016) for the identification of a triphthong.

A pilot testing is done for confirming the listening comprehension of linguists for the achievement of better results. Therefore, confusing words have been included in audio test files. After getting the consensus, the actual experiment is started. Word list (containing triphthongs) has been recorded which caters the articulation at initial, medial and final positions of word. Then, the respondents have listened all utterances very carefully and count the number of syllables in a word. After considering this syllable count log-sheet, the idiosyncratic acoustic behavior of triphthongs has been confirmed in PakE. The initial results reported that there are two different triphthongs (/vae/ and /var/) and a diphthong /or/ in PakE which are not the part of RP phonetic inventory.

Table 1. The checklist for auditory analysis of Triphthong in PakE

\begin{tabular}{|c|c|c|c|c|}
\hline & & Phonological Transcription & No. of Syllables & Identification \\
\hline 1 & Boy, toy, joy, enjoy & /oI/ $\rightarrow$ /vae/ & 1 & Triphthong \\
\hline 2 & Boil, coil, join, coin, choice, point & /or/ $\rightarrow$ /val/ & 1 & Triphthong \\
\hline 3 & Voice, noise, soil, toilet, avoid & /OI/ $\rightarrow$ /oI/ & 1 & Diphthong \\
\hline
\end{tabular}

\subsection{Acoustic Experiment Methodology}

Afterwards, acoustic analysis is done by using spectral clues. The spectral analysis shows that there are two different triphthongs in PakE. The acoustic behavior of triphthongs reported that PakE has idiosyncratic features which are not the part of RP phonetic inventory. The selected corpus is designed for the justification whether Pakistani English speakers can pronounce /oI/ diphthong or any other alternative segment. Therefore, data selection and analysis have been done and results confirmed that;

1) Pakistani English speakers are unable to articulate / $/ \mathrm{I} /$ diphthong because we merge the $/ \mathrm{J} / \mathrm{and} / \mathrm{o} /$ vowels. Along with this, at medial position /I/ is articulated as it is but we cannot articulate short (/I/) vowel at word final position due to the extra metrical rule and influence of our first language, Urdu. Therefore, short vowel converts into long vowel but short vowel /I/ converts into long vowel /e/ (Farooq \& Mahmood, 2017). The reason behind the conversion of $/ \mathrm{I} /$ into /e/ vowel may be the nearby place of articulation of $/ \mathrm{o} / \mathrm{vowel}$.

2) /vae/ triphthong would be articulated when a gliding sound appears at word final position e.g. boy, joy, toy, etc.

3) /var/ triphthong would be articulated when a gliding sound is followed by an alveolar stop or a lateral stop e.g., point, voice, coil, etc. 


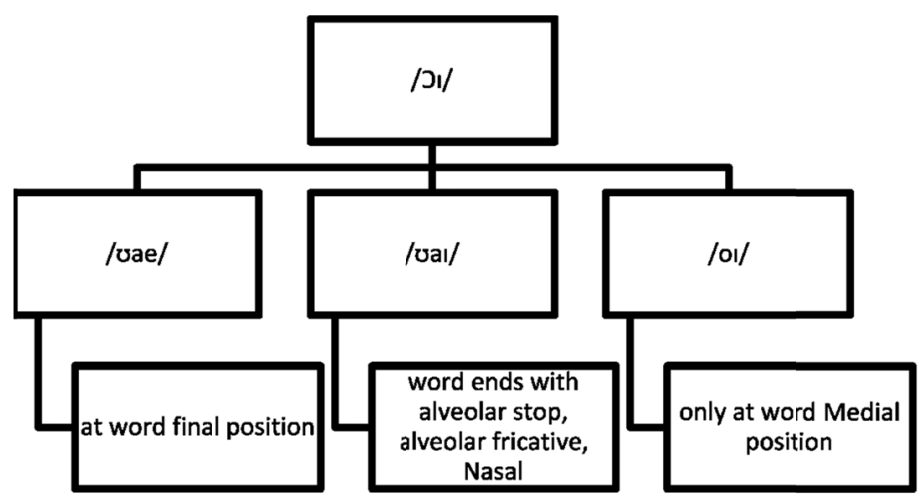

Figure 2. Acknowledgement of Triphthongs in Pakistani English

\section{Discussion}

Segmental duration and formant frequencies are analyzed at a normal speaking rate. Average values are calculated by enlisting their values among male and female Pakistani English speakers which have been enlisted in table. Firstly, vocalic segments have been selected or rejected on the bases of duration.

1) All unstressed diphthongs have segmental duration around 300 milliseconds (or below). This duration also supported in the past research for the diphthongs in Pakistani English (Farooq \& Mahmood, 2017) and in Pakistani Urdu (Khurshid, Usman, \& Javaid, 2003-2004; Bhatti \& Mumtaz, 2016).

2) Strangely, unstressed segmental duration of a triphthong has been observed equal to a diphthong i.e. around 300 milliseconds or below. According to literature review, in RP triphthongs, the middle vowel is confusing (2.2.4.).

Table 2: Vocalic Sequences and their Duration in Pakistani English

\begin{tabular}{|c|c|c|c|}
\hline & \multicolumn{2}{|c|}{ Average of Unstressed Duration of Triphthongs in Pakistani English (ms. } \\
\hline & & Males & Females \\
\hline 1 & oI $\rightarrow /$ oI $/$ & 223 & 220 \\
\hline 2 & or $\rightarrow /$ vae/ ${ }^{*}$ & 245 & 263 \\
\hline 3 & oI $\rightarrow / \mathrm{vaI}^{* \pi}$ & 249 & 263 \\
\hline
\end{tabular}

Note. */vae/ is a suggested triphthong in Pakistani English variety. **/vai/ is a suggested triphthong in Pakistani English variety.

Formant frequencies of identified vocalic segments (i.e. one diphthong and two triphthongs) have been manually analyzed in PRAAT. Therefore, first formant (F1) and second formant (F2) are measured while remaining formants (i.e., F3, F4, F5) are ignored as they are not much supportive. A diphthong can be divided into three parts i.e. on glide, transition period and off glide (2.2.3.). A triphthong has been divided into five parts as it has two transition periods along with on glide and off glide. Presently, transition period is used for the acoustic identification of diphthong and triphthongs. Three instances of every vocalic segment (in 3060 utterances) have been measured and their average values are reported in the following table.

Table 3. Vocalic segments and their formant frequencies in PakE

\begin{tabular}{|c|c|c|c|c|c|c|}
\hline & $\begin{array}{l}\text { Vocalic } \\
\text { segments }\end{array}$ & $\begin{array}{l}\text { Average Formant } \\
\text { (ms.) }\end{array}$ & Values of Males' Triphthongs & $\begin{array}{l}\text { Average Formant } \\
\text { Triphthongs (ms.) }\end{array}$ & Values of & Females' \\
\hline & & F1 & $\mathrm{F} 2$ & F1 & $\mathrm{F} 2$ & \\
\hline 1 & oI $\rightarrow$ /oI/ & 753 & 1453 & 779 & 1700 & \\
\hline 2 & or $\rightarrow$ /Uae/ & 624 & 1298 & 676 & 1298 & \\
\hline 3 & əI $\rightarrow$ /val/ & 626 & 1300 & 676 & 1330 & \\
\hline
\end{tabular}

Places and manners of articulation of one diphthong and two triphthong of PakE have been displayed in the figure below by using the values of table 3 . 

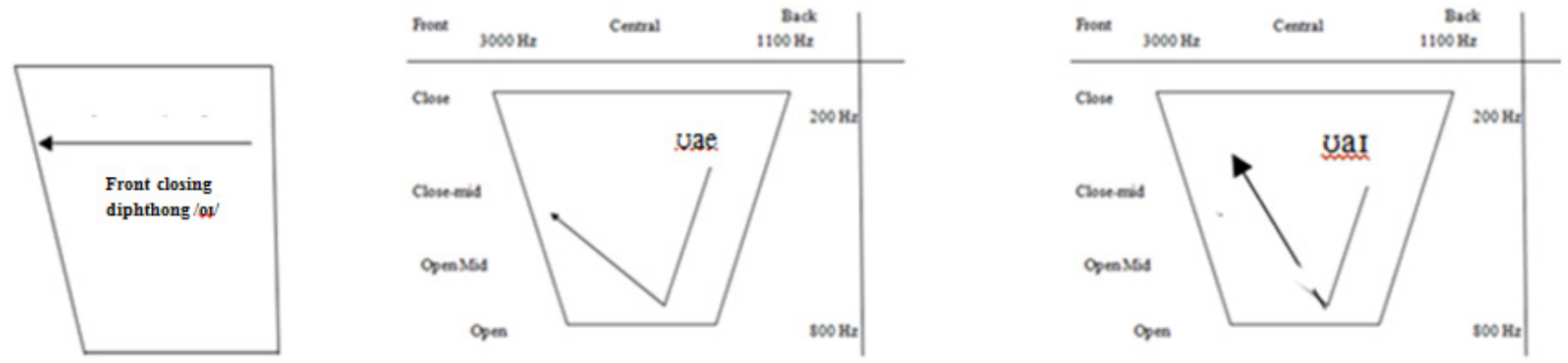

Figure 3. Places and manners of articulation of diphthong and triphthongs in PakE

In Pakistan, Urdu is our national language along with this English is an official language and a compulsory subject (2.1.). In fact, English should be our second language but fortunately or unfortunately it is considered more important than our first languages. Therefore, in this study, the speech of Pakistani English speakers has been acoustically analyzed in PRAAT and results confirmed that RP or BBC English is different from Pakistani English variety.

4) Pakistani English has two triphthongs i.e., /vae/ and /va/ which are confirmed by auditory and acoustic experimentations.

5) Both triphthongs have been identified at word medial and final positions but not word initial position.

6) In the present study, only one diphthong is reported by using auditory method and also acoustically confirmed by the researcher.

The present work confirmed the contrastive nature and acoustic differences of PakE. It is also concluded that first language, Urdu phonetically influences speech of Pakistani English speakers. The nativeness effect also influences word syllabification, vowel duration and formant frequencies of vocalic segments. The results of data analysis confirm that there are two triphthongs (/vae/ and /vai/) which substitute /sI/ diphthong. /vae/ triphthong appears at word final position while and /va/ triphthong comes word medially. These results are based on the speech corpus collected by sixty speakers. PakE speakers cannot articulate short vowel at word final position due to the extra metrical rule and the nativeness effect of Urdu language. Consequently, we can say that PakE would become an independent variety by the addition of these triphthongs.

Acoustically, PakE is different from British English therefore this study will be helpful for English Language Learning (ELL) in Pakistan. But the research is presently limited to minimum number of speakers and speech corpus. Therefore, the research will be done in future by increasing the number of speakers and corpus which would give more evident results. Accent variation and phonological rules will also be investigated in future which ultimately would acknowledge PakE as an independent variety.

\section{Acknowledgement}

This research is conducted as a semester project and pilot testing for my $\mathrm{Ph}$. D. thesis at Government College University, Faisalabad. I am thankful to all voluntary participants whose speech supports me in my research. I am also thankful to my supervisor Dr. Asim Mahmood for helping me in my queries.

\section{References}

Ahmad, S., \& Ali , S. (2014). Impact of Urduised English on Pakistani English Fiction. Journal of Research (Humanities), 61-75.

Amberg, J. S., \& Vause, D. J. (n. d.). Introduction: What is Language? American English: History, Structure, and Usage (978-0-521-85257-9), 1-10.

Bhatti, R., \& Mumtaz, B. (2016). Conference of Language and Technology, CLT16. 6 (pp. 1-8). Lahore: Center for Language Engineering, University of Engineering and Technology, Lahore.

Bilal, H. A., Mahmood, A. M., \& Saleem, R. M. (2011). Merger of /e/ and /æ/ in Punjabi English. Internation Journal of Academia Research, 3(6), 407-412.

Bilal, H. A., Mahmood, M. A., \& Saleem, R. M. (2011). Acoustic Analysis of Front Vowels in Pakistani English. Internation Journal of Academic Research, 3(6), 20-27. 
Bilal, H. A., Mahmood, M. A., \& Saleem, R. M. (2011). Merger of /i:/ and /I/ in Pakistani English. International Journal of Linguistics, 3(1: E34), 1-12. https://doi.org/10.5296/ijl.v3i1.1041

Boersma, P. (2013). Acoustic Analysis. In R. Podesva, \& D. Sharma (Eds.), Research Methods in Linguistics (pp. 1-21). Cambridge: Cambridge University Press.

Boersma, P., \& Weenink, D. (1992-2013). www.praat.org. (Institute of Phonetic Sciences, University of Amsterdam) Retrieved from Praat: Doing Phonetics by Computer: http://www.fon.hum.uva.nl/praat/

Boersma, P., \& Weenink, D. (n. d.). www.praat.org. (Institute of Phonetic Sciences, University of Amsterdam) Retrieved from Praat: Doing Phonetics by Computer: http://www.fon.hum.uva.nl/praat/

Crystal. (1985, (2003)). What is Phonetics?, 5. (E. E. Loos, H. Dwight, J. Day, P. C. Jordan, D. J. Wingate, Editors, \& SIL International, 2004) Retrieved from About Lingual Links: http://www-01.sil.org/linguistics/GlossaryOfLinguisticTerms/WhatIsPhonetics.htm

Deterding, D. (2010). Variation across Englishes: Phonology. In A. Kirkpatrick (Ed.), The Routledge Handbook of World Englishes (pp. 385-396). Taylor and Francis Group: London and New York.

Emerich, G. H. (2012). The Vietnamese Vowel System. (Ph. D. Dessertation). (J. Yuan, Ed.) Anthropological Linguistics and Sociolinguistics Commons, and the Asian Studies Commons: University of Pennsylvania.

Fant, G. (2006). Acoustic Aspects of Speech. Speech Acoustics and Phonetics: Selected Writings, 24, p. 153. Berlin: Springer Science \& Business Media.

Farooq, M. (2015). An Acoustic Phonetic Study of Six Accents of Urdu in Pakistan. (Unpublished Thesis). Lahore, Pakistan: University of Manangement and Technology, Johar Town, Lahore.

Farooq, M., \& Mahmood, D. A. (2017). Acoustic Analysis of Triphthongs in th Speeh of Pakistani English Speech (unpublished).

Farooq, M., \& Mahmood, D. A. (2017). Acoustic Behavior of RP Diphthongs in Pakistani English (PakE) (inprocess). Lasbella University.

Hillenbrand, J. M. (2013). Static and Dynamic Approaches to Vowel Perception. In G. S. Morrison, P. F. Assmann, \& W. M. Hartmann (Ed.), Modern Acoustics and Signal Processing. Berlin: Springer. https://doi.org/10.1007/978-3-642-14209-3_2

Hulya. (2009). Comparing and Contrasting First and Second Language Acquisition: Implications for Language Teachers. English Language Teaching: CCSE Org., 2(2), 155-163.

Hussain, Q., Mahmood, R., \& Mahmood, M. A. (2011). Vowel Substitution: A Comparative Study of English Loans in Punjabi and Urdu. International Journal of Linguistics, 3(1:E31), 1-13. https://doi.org/10.5296/ijl.v3i1.1022

Hussain, S. (1997). Phonetic Correlates of Lexical Stress in Urdu.

Kachru, Y. (2005). Hindi-Urdu. In B. Comrie (Ed.), The Major Languages of South Asia, The Middle East and Africa (pp. 37-53). London: Routlege Taylor and Francis Group.

Kachru, Y. (2008). In B. B. Kachru, Y. Kachru, \& S. N. Sridhar (Eds.), Language in South Asia (pp. 81-102). Cambridge: Cambridge University Press. https://doi.org/10.1017/CBO9780511619069.006

Kavaliauskiene, G. (2009). Role of Mother Tongue in Learning English for Specific Purposes. ESP World, 8(1 (22)), 1-12.

Khan, H. I. (2012). The Evolution of Pakistani English (PakE) as a Legitimate Variety of English. International Journal of Applied Linguistics \& English Literature, 1(5), 90-99. https://doi.org/10.7575/ijalel.v.1n.5p.90

Khurshid, K., Usman, S. A., \& Javaid, N. (2003-2004). Possibility of Existence and Identification of Diphthongs and Triphthongs in Urdu Language. Lahore: CRULP.

Khurshid, K., Usman, S. A., \& Javaid, N. (2003-2004). Possibility of Existence and Identification of Diphthongs and Triphthongs in Urdu Language. Center for Language Engineering, UET, Lahore, CRULP Annual Student Report.

Kitagawa, A. (n. d.). Acoustic Characteristics of English Diphthongs Produced byJapanese Learners. Proceedings of the 17th Conference of Pan-Pacific Association of Applied Linguistics, 17, pp. 99-100.

Kohnlein, B. (n. d.). Synchronic Alternations Between Monophthongs and Diphthongs in Franconian: a Metrical Approach. In W. D. Gruyter (Ed.), Segmental Structure and Tone. 
Koucka, A. (2007). The Role of Mother Tongue in English Language Teaching. University Of Pardubice, Faculty of Arts and Philosophy, Department of English and American Studies.

Lee, S., Potamianos, A., \& Narayanan, S. (2014). Developmental Acoustic Study of American English Diphthongs. Acoustical Society of America, 136(4), 1880-1894. https://doi.org/10.1121/1.4894799

Lewis, P. M., Simons, G. F., \& Fen, C. D. (2016). Pakistan. Retrieved from Ethnologue: Languages of the World: https://www.ethnologue.com/country/PK/status

Mahajan, T. (Ed.). (2014). Kinds of Vowels-Monophthongs and Diphthongs. Retrieved from English Grammar: http://blogsenglishgrammar.blogspot.com/2014/12/kind-of-vowels-monophthong-diphthong.html

Mahboob, A. (2011). English: The industry. Journal of Postcolonial Cultures and Societies (JPCS), 2(4), 46-61.

Mahboob, A., \& Ahmar, N. H. (2004). Pakistani English: Phonology. In E. W. Schneider (Ed.), A Handbook of Varieties of English: a Multimedia Reference Tool (pp. 1002-1017). Burlin, New York: Mouton de Gruyter.

Mahboob, A., \& Jain, R. (2016). Bilingual Education in Pakistan and India. In O. Garcia, A. Lin, \& S. May (Eds.), Bilingual and Multilingual Education, 1-14. https://doi.org/10.1007/978-3-319-02324-3_15-1

Mahboob, A., \& Szenes, E. (2010). Construing Meaning in World Englishes. In A. Kirkpatric (Ed.), The Routledge Handbook of World Englishes (Vol. 1, pp. 580-581). London and New York: Taylor and Francis Group.

Mahmood, R., Hussain, Q., \& Mahmood, A. (2011). Phonological Adaptations of English Words Borrowed into Punjabi. European Journal of Social Sciences, 22(2), 234-245.

Man, C. Y. (2007). An Acoustical Analysis of the Vowels, Diphthongs and Triphthongs in Hakka Chinese. 16th International Congress of Phonetic Sciences (ICPhS). XVI. Saarbrücken, Germany: ICPhS.

McGuigan, B. (2016). wiseGEEK: Clear Answers for Common Questions. (N. Foster, Editor, \& Conjecture Corporation 2003-2016). Retrieved from http://www.wisegeek.org/what-is-phonetics.htm

Mehboob, A. (2003). The Future of English in Pakistan. SPO Discussion Paper Series II, 1-28. Islamabad, Pakistan: Strengthening Participatory Organization.

Modern Englishes. (2012). English Today: Forms, Functions, and Uses (pp. 203-223).

Nolan, F. (2006). What is phonetics? (I. Edmonds, Editor, C. Williams, Producer, \& BAAP) Retrieved from British Association of Academic Phoneticians (BAAP): http://www.baap.ac.uk/phonetics.html

Oxford Urdu English Dictionary. (2013). Pakistan: Oxford Publication.

Ramanujan, A. K. (1990). Sociolinguistic Variation and Language Change. In W. Bright (Ed.), Language Variation in South Asia (2 46897531 ed., pp. 11-18). New York: Oxford University Press.

Rehman, D. T. (2006). Urdu as an Islamic Language-the Annual of Urdu Studies. In M. U. Memon (Ed.) Urdu Studies, 22, 101-119.

Rehman, T. (2002). Language Ideology and Power: Language Learning among the Muslims of Pakistan and North India (illustrated edition., Vol. xix). Oxford: Oxford University Press.

Riaz, M. (2015). Pakistani English: Deviant Pronunciation of English Words by Uneducated Native Punjabi Speakers. Journal of Second and Multiple Language Acquisition-JSMULA, 3(2), 23-33.

Roach, P. (2009). Long Vowels, Diphthongs and Triphthongs. In P. Roach, English Phonetics and Phonology: A Practical Course (4 edition, pp. 16-21). New York, UK: Cambridge University Press.

Roach, P. (2009). Speech Articulation. In P. Roach, English Phonetics and Phonology: A Practical Course (4th edition). Cambridge: Cambridge University Press.

Roach, P. (2009). Voicing and Consonants. In P. Roach (Ed.), English Phonetics and Phonology: A Practical Course (4th ed., Vol. 1, pp. 22-30). Itlay: Cambride University Press.

Romaine, S. (1994). Language in Society: An Introduction to Sociolinguistics. Oxford: Oxford University Press.

Rose, P., \& Wang, X. (2016). Cantonese forensic voice comparison with higher-level features:likelihood ratio - based validation using F-pattern and tonal F-trajectories over a disyllabic hexaphone. Odyssey (pp. 326-333). Bilbao, Spain. https://doi.org/10.21437/Odyssey.2016-47

Sarwar, A., Ahmed, S., \& Tarar, A. A. (2003). Diphthongs in Urdu Language and Analysis of their Acoustic Properties. Annual Student Report, Center for Research in Urdu Language Processing (CRULP). 
Schneider, E. W. (2010). Developmental Patterns of English: Similar or Differt? In A. Kirkpatrick (Ed.), The Routledge Handbook of World Englishes (pp. 371-379). London and New York: Taylor and Francis Group.

Sharifian, F. (2004). Semantic and Pragmatic conceptualizations within an Emerging Verity: Persian English. In A. Kirkpatrick (Ed.), World Englishes: Implications for International Communication and English Language Teaching. Hong Kong Institute of Education. Cambridge: Cambridge Uuniversity Press.

Sharifian, F. (2004). Semantic and Pragmatic conceptualizations within an Emerging Verity: Persian English. In A. Kirkpatrick (Ed.), World Englishes: Implications for International Communication and English Language Teaching. Hong Kong Institute of Education. Cambridge: Cambridge Uuniversity Press.

Skandera, P., \& Burleigh, P. (2005). Lesson 3: Consonants. In G. N. V. Tubingen (Ed.), A Manual of English Phonetics and Phonolgy: Twelve Lessons with an Integrated Course in Phonetic Transcription (pp. 19-30). Germany: Narr Francke Attempto Verla.

Tema. (n. d.). The Role of the Mother Tongue in Second Language Learning.

Trudgill, P. (1992). Interoducing Lnaguage and Society (1 edition, Vol. 1). (D. Crystal, Ed.) Middlesex, England: Penguin Group, Clays Ltd.

Waqar, A., \& Waqar, S. (2002). Identification of Dihthongs in Urdu and their Acoustic Properties.

Weirich, M. (2011). The Influence of NATURE and NURTURE on Speaker-Specific Parameters in Twins' Speech: Acoustics, Articulation and Perception (Ph. D. Dissertation). (P. Schwalm, Ed.) Humboldt-Universität zu Berlin.

Wells, J. (2009). Triphthongs, anyone? Retrieved from John Well's Phonetic Blog: http://phonetic-blog.blogspot.com/2009/12/triphthongs-anyone.html

Wells, J. C. (1982). vowels. In J. C. Wells (Ed.), Accents of English (X edition). The British Isles, Cambridge: Cambridge University Press.

Zia, W. (Ed.). (2011). Pakistan 6th Population and Housing Census-Pakistan. Retrieved from http://www.paknetmag.blogspot.com/2011/..../2011-pakistan-6th-population

\section{Copyrights}

Copyright for this article is retained by the author(s), with first publication rights granted to the journal.

This is an open-access article distributed under the terms and conditions of the Creative Commons Attribution license (http://creativecommons.org/licenses/by/4.0/). 